Article

\title{
Recycling of Coking Plant Residues in a Finnish Steelworks-Laboratory Study and Replacement Ratio Calculation
}

\author{
Hannu Suopajärvi ${ }^{1}{ }^{1 *}$, Antti Salo ${ }^{1}$, Timo Paananen ${ }^{2}$, Riku Mattila ${ }^{1}$ and Timo Fabritius ${ }^{1}$ \\ 1 Laboratory of Process Metallurgy, University of Oulu, P.O. Box 4300, FI-90014 Oulu, Finland; \\ E-Mails: saloanttijohannes@gmail.com (A.S.); riku.mattila@oulu.fi (R.M.); \\ timo.fabritius@oulu.fi (T.F.) \\ 2 Ruukki Metals Oy, Rautaruukintie 155, FI-92100 Raahe, Finland; E-Mail: timo.paananen@ruukki.com \\ * Author to whom correspondence should be addressed; E-Mail: hannu.suopajarvi@oulu.fi; \\ Tel.: +358-50-575-1471; Fax: +358-8-553-2339.
}

Received: 6 March 2013; in revised form: 23 April 2013 / Accepted: 25 April 2013 /

Published: 6 May 2013

\begin{abstract}
Material efficiency is one of the most effective methods for achieving more sustainable operations in iron and steelmaking. Sintering and briquetting processes are commonly used in integrated steel plants to recycle carbon- and iron-containing residues back to blast furnace. In the Ruukki steelworks in Finland, a surplus of solid coking plant by-products is produced, none of which are presently utilized within the steelworks. In this paper, a novel concept for recycling solid coking plant by-products to a blast furnace via liquid-solid injection is evaluated. According to the conducted laboratory study, all the solid by-products could be utilized via liquid-solid mixture injection. By pulverizing the coke gravel and coke sand and mixing it with extra heavy bottom oil, the annual coke requirement of a blast furnace could be decreased by almost $9 \%$ with constant oil injection and could reduce annual oil requirements by almost $39 \%$ with constant coke rate. Evaluation of direct and indirect environmental impacts reveals that there would be more positive than negative impacts when recycling solid coking plant by-products inside steel plant boundaries.
\end{abstract}

Keywords: reducing agent; recycling; coking plant; blast furnace; viscosity measurement; replacement ratio 


\section{Introduction}

Material efficiency has been identified as one of the key issues in steel production with respect to minimizing the need of virgin raw materials, reducing waste and saving energy. A majority of steel today is produced by using the integrated blast furnace-basic oxygen furnace (BF-BOF) route where iron oxides are reduced and melted into hot metal in BF and refined into steel in BOF [1]. Some integrated steel plants have their own coking plants which produce coke for use as a blast furnace reducing agent.

Integrated steel plants are complex entities with crossing material and energy flows. A number of residues are produced inside the system boundaries, some of which are utilized inside the steel work unit processes. Sintering, which is a unit process to agglomerate iron ore fines in high temperature, has been traditionally used to refine many of the solid residues produced inside the system boundaries [2,3]. In steel plants that do not include a sintering plant, solid iron-bearing residues can be recycled back to the blast furnace via a briquetting plant where cement-bonded briquettes are produced [4]. Another option for treating dust and scales is to use alternative recycling technologies, e.g., Oxycup or rotary hearth furnace (RHF) [5].

Best Available Techniques Reference (BREF) guidelines have been created within the European Integrated Pollution Prevention and Control (IPPC) Bureau to organize and exchange information between European Union (EU) member states and industries [6]. These guidelines are used, e.g., by industrial operators when applying for IPPC permits and by environmental authorities. The goal of IPPC is to decrease the environmental burden of industrial operations. One aim in particular is decreasing raw material usage and energy use by increasing internal recycling and reuse.

The BREF document for iron and steel production [6] provides Best Available Techniques (BAT) measures for enhancing coking plant and blast furnace environmental efficiency. BAT for coking plant suggest that residues, especially tar and still effluent, should be recycled back to the coal feed of the coking plant. For coke oven gas (COG), BAT prescribes using the gas as fuel or reducing agent or for the production of chemicals. BAT for resource management of blast furnaces implies reducing coke consumption by injecting various reducing agents and wastes, such as metallic residues, used oils and emulsions, oily residues, fats and waste plastics, through the tuyéres located in the lower part of the blast furnace.

Utilization of coking plant liquid by-product coal tar and solid residues, coke gravel, coke sand and coke dust as blast furnace reducing agents could increase the resource efficiency of steel production and decrease coke or tuyére-injected reducing agent consumption, thus complying with the objectives of blast furnace and coking plant BAT. Reducing agents used in the blast furnace can be fed from the top and from the lower part of the furnace. Metallurgical coke is top-charged and it has the important function of supporting the iron burden as it descends in the furnace. Additionally auxiliary fuels are injected from the lower part of the furnace with a hot blast to reduce the coke consumption and to make the controllability of the furnace easier. Several auxiliary injection technologies and fuels are available for BF. Pulverized coal, oil, natural gas and waste plastics can be injected from the tuyéres.

Injection equipment largely determines the use of auxiliary reducing agents. While the technologies for liquid, solid and gaseous reducing agents differ, coal-oil-injection has been reported to be feasible in an injection system originally developed for liquid injection, with only minor modifications [7]. 
Such a system is proposed in this paper for utilizing liquid and solid residues from a coking plant as blast furnace reducing agents. The paper presents the results of viscosity measurements in which pulverized coking plant by-products from Ruukki steelworks in Raahe, Finland, were mixed into extra heavy bottom oil and coal tar. According to the measurements, the total amount of solid by-products currently produced in the coking plant could be recycled into the blast furnace as supplementary reducing agents. Implementing coking plant by-product use in the blast furnace could decrease the amount of required reducing agents significantly. According to reducing agent requirement calculations based on coke replacement ratios, the coke consumption could be decreased by almost $9 \%$.

\section{Methods}

\subsection{System Boundaries}

An integrated steel plant is a complex entity of material and energy flows between different unit processes. Ruukki integrated steelworks in Raahe is one of the top steel producers when measured in environmental performance. Until the end of the year 2011, Ruukki had a sintering plant that was used in recycling the majority of the internal iron- and carbon-bearing materials back to the ironmaking process, i.e., to blast furnace. The shutdown of the sintering plant reduced the carbon footprint of Ruukki's production, but a new solution for internal material recycling was needed. A briquetting line was constructed that can process iron-bearing materials into suitable form for feeding to the blast furnace.

Besides iron-containing by-products, which have been reviewed thoroughly in the work of Makkonen et al. [8], carbon-containing by-products are also produced inside the steel plant system boundaries, more precisely in the coking plant. Some 1,200,000 $\mathrm{t}$ of coking coal is used to produce $800,000-900,000 \mathrm{t}$ of metallurgical coke in Ruukki coking plant annually. Coke is used as the primary reducing agent in two blast furnaces. Coke oven gas, composed mainly of $\mathrm{H}_{2}, \mathrm{CH}_{4}$ and $\mathrm{CO}$ with heating value of $16-18 \mathrm{MJ} / \mathrm{Nm}^{3}$, is utilized chiefly in the steel plant processes. Sulfur and benzene are sold as by-products to other industries. Figure 1 presents the proximate values of amounts of coking plant by-products produced in 2011. The amount of coke produced was approximately 790,000 $\mathrm{t}$.

Nut coke is used as a reducing agent in the BF where it is mixed with iron ore and coke layers. Coal tar had previously been sold to other industries, but it is an effective reducing agent with a high coke replacement ratio and thus has been used as a reducing agent at Ruukki since 2012. It has been proposed that coal tar could also be utilized in direct reduced iron (DRI) production after pressurized gasification [9]. The coke dust produced at Ruukki is utilized in cold-bonded briquettes, but coke gravel and coke sand are currently sold. Additionally, some amount of spillage coke is produced, but as it has high moisture content, it is not considered here.

Beside the above-mentioned measures to recycle internal carbonaceous materials, this paper also proposes a liquid-solid injection practice that could further increase the use of carbonaceous by-products inside steel plant. In Figure 2a, the recycling scheme at Ruukki integrated steel plant before the closing of sintering plant is presented. Figure $2 \mathrm{~b}$ demonstrates the current use of coking plant by-products (solid lines) and proposed, additional use (dashed lines). It is proposed in this paper that solid residues from coke production could be mixed with liquid injectant, extra heavy bottom oil, referred to as oil in the text, and coal tar. 
Figure 1. Proximate amount of by-products from Ruukki coking plant in 2011.

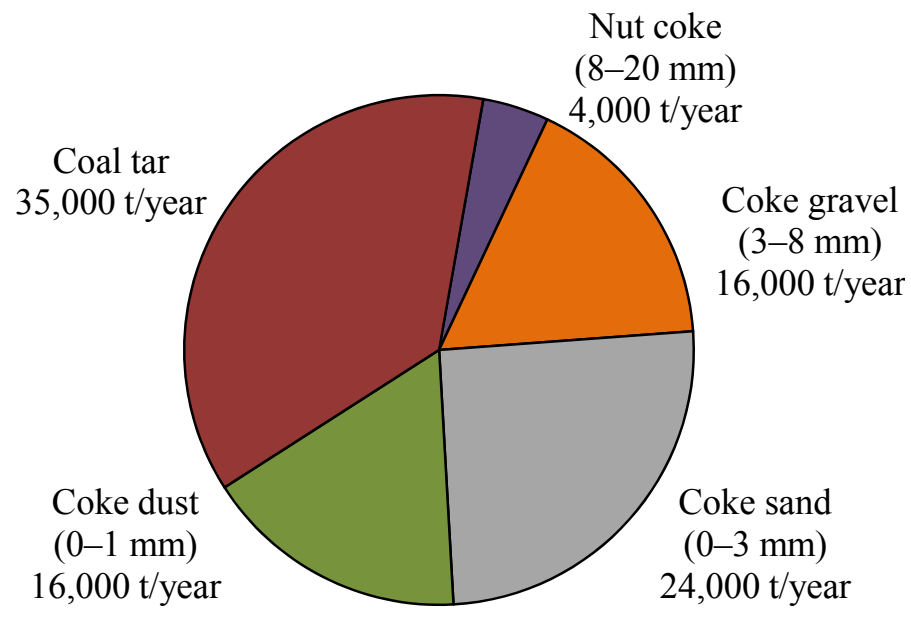

Figure 2. Coking plant residue recycling in Ruukki steel plant.

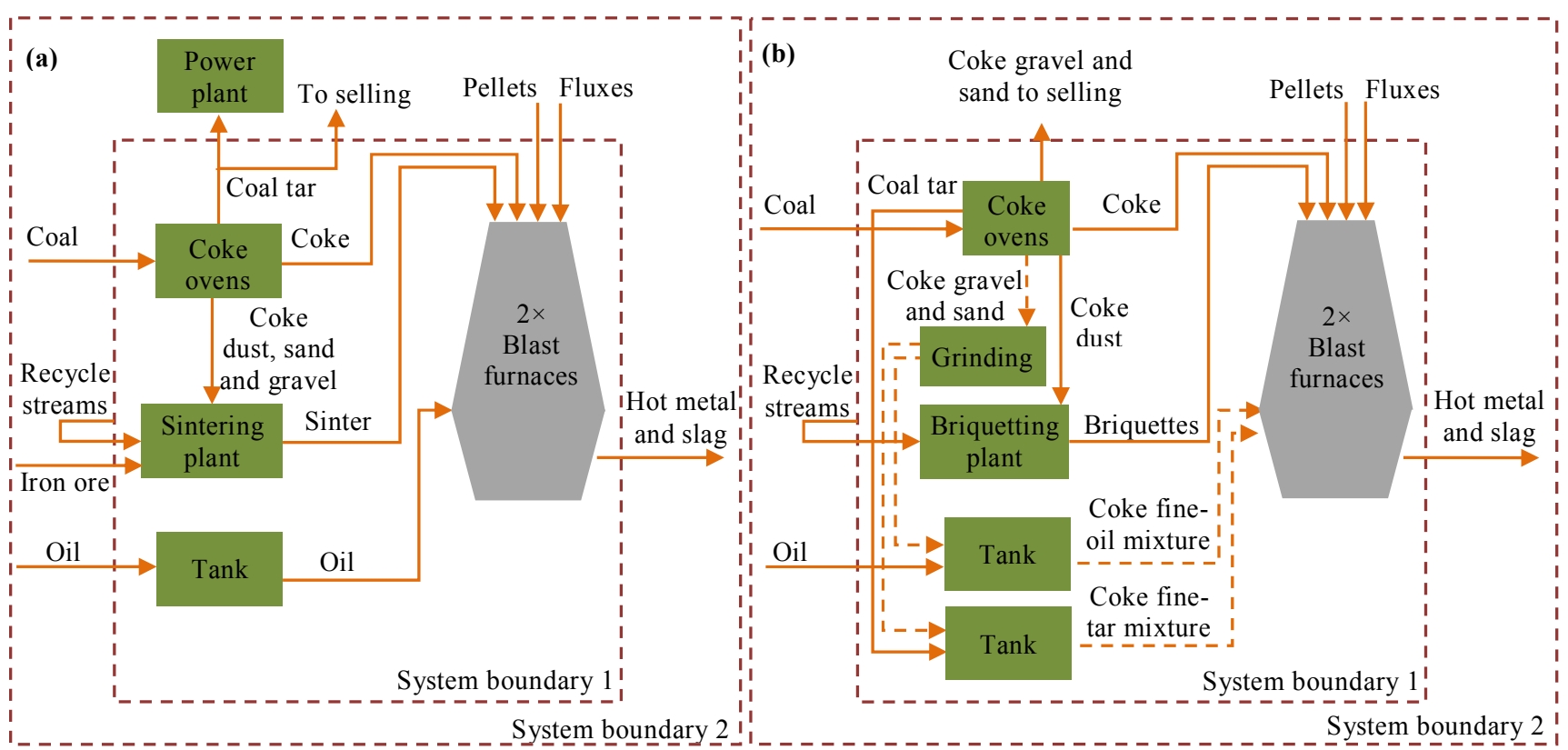

The technological feasibility of the proposed system is largely based on the physical properties of the injected reducing agent. The viscosity of the liquid-solid mixture is identified as the most important parameter affecting the feasibility of the by-product utilization as injection fuel in BF.

\subsection{Viscosity Measurement and Stability of the Liquid-Solid Mixture}

The oil, coal tar and coking plant by-products used in the study were received from Ruukki steelworks. Oil is a bottom product from crude oil refining and coal tar is separated from the raw coke oven gas in gas treatment plant. The solid by-products used in the viscosity measurements were coke gravel and coke sand. The particle size of the coke gravel ranged from 3 to $8 \mathrm{~mm}$ and coke sand 0-3 mm, respectively.

The preparation of coking plant residues for viscosity measurement included grinding and sieving of the samples. The sieve used was 200 mesh and particle size distribution was measured with a 
Beckman Coulter LS 13320 (Brea, CA, USA) particle size analyzer. Of the particles, 90\% were below $80.7 \mu \mathrm{m}$. The by-products (coke gravel, coke sand and coke fines) from the coking plant would be high quality for use in reducing agent application. In Table 1, the chemical composition of coke gravel, coke sand and coke fines from Ruukki coking plant is compared to the composition of coke and two pulverized coals (PC) [10]. The total carbon of the PC 1 was $80.0 \%$ and PC $282.8 \%$, respectively. The amount of ash in coking plant by-products is slightly higher than in pulverized coals, but still in acceptable range. The chemical composition of the by-products is comparable to coke with a very low share of volatile matter. The share of carbon and the share of the unwanted elements such as (Na, K and S) do not differ significantly from that of coke. The composition of oil used as injected reducing agent in normal operation is as follows: carbon $(\mathrm{C}) 87 \%$, hydrogen $(\mathrm{H}) 10.5 \%$ and sulfur $(\mathrm{S}) 2.0 \%$. The ash content is low, $0.02 \%$ and net calorific value high, $40.0 \mathrm{MJ} / \mathrm{kg}$ [11]. Higher heating values calculated from the proximate analysis [12] for coke, coke gravel, coke sand and coke dust are 31.1, $30.3,31.1$ and $31.3 \mathrm{MJ} / \mathrm{kg}$ (dry basis, $\mathrm{db}$ ) respectively.

Table 1. Chemical analysis of coking plant by-products, coke and two pulverized coals (PC 1-PC 2).

\begin{tabular}{|c|c|c|c|c|c|c|c|}
\hline \multirow{2}{*}{ Carbon-bearing material } & \multicolumn{4}{|c|}{ Chemical analysis (wt \%) } & \multicolumn{3}{|c|}{ Ash analysis (\% in ash) } \\
\hline & $\mathbf{C}_{\text {fixed }}$ & Volatile matter & $\mathbf{S}$ & Ash & $\mathrm{SiO}_{2}$ & $\mathrm{CaO}$ & $\mathbf{A l}_{2} \mathbf{O}_{3}$ \\
\hline Coke gravel & 86.0 & 0.24 & 0.72 & 12.6 & 59.7 & 2.8 & 25.7 \\
\hline Coke sand & 88.0 & 0.23 & 0.78 & 11.7 & 55.6 & 4.6 & 25.5 \\
\hline Coke dust & 88.6 & 0.23 & 0.81 & 11.1 & 53.3 & 6.2 & 25.3 \\
\hline Coke & 88 & ND & 0.6 & 9.6 & 56.3 & 2.4 & ND \\
\hline PC 1 & ND & 30.4 & 0.3 & 7.5 & ND & ND & ND \\
\hline $\mathrm{PC} 2$ & ND & 8.6 & 0.4 & 10.3 & ND & ND & ND \\
\hline
\end{tabular}

Viscosity measurements were conducted with a Searle-type rotation viscometer. A HAAKE VT550 (Thermo Fisher Scientific, Waltham, MA, USA) viscometer was combined with on-line computer measurements. The test sample was heated to the desired temperature with water bed or, for higher temperatures, in an electric furnace. Temperature was measured from the furnace, near thermal element and from the top of the sample. Viscosity measurements were made according to the temperature of the sample.

The rotation viscometer was found to be suitable for viscous oils at high temperatures. The test apparatus was calibrated by using calibration liquids (RT10, RT50, RT500 and RT1000) with specified viscosity values at different temperatures. The viscometer gave reliable results between viscosities of 10-1000 centipoise (cP). Variation in the results was highest with viscosity values below $10 \mathrm{cP}$ and smallest when viscosity was above $100 \mathrm{cP}$.

In viscosity measures, Job manager software of HAAKE Rheowin (Thermo Fisher Scientific) was used. The ramp setup was used to evaluate the rheological behavior of the liquids and liquid-solid mixtures. Time curve setup was used to measure viscosity values of Newtonian liquids/mixtures with constant shear rate. The rheological properties of the test samples were assessed between shear rates of 0-114 1/s. The temperatures at which the viscosity of liquids and mixtures were measured were taken within the possible temperature regime of blast furnace injection temperature. The amount of solids 
(pulverized coking plant by-products) was below $60 \%$ of mass share and the measuring time was 300-600 s. Standard deviation was calculated from the mean viscosity for each sample.

All viscosity measurements followed the same procedure. The sample was poured into a crucible that was then placed into the electric furnace. The measurement rotor was placed in the sample and the furnace temperature was raised. All the solid material additions were done through the lid in the furnace. Before measuring the viscosities, the solid particles were mixed into the liquid by adjusting the rotor up and down and spinning it. After every test series, the sample crucible and rotor were cleaned with steel wool, hot water and a degreasing agent.

Oil and coal tar are stored in tanks before their injection to the BF, which enables the descent of the solids to the bottom of the tank. Simple stability test was done to evaluate the sedimentation phenomenon of the solids. Test tubes filled with oil and oil-coke fine mixtures were held in the temperature of $170{ }^{\circ} \mathrm{C}$ for different periods of time. Reference sample (oil) was held 8 days and oil-coke fine mixtures one, five and eight days in the heating furnace. Test tube filled with coal tar was held for seven days and coal tar-coke fine mixtures for one, four and seven days in the temperature of $70{ }^{\circ} \mathrm{C}$ The mass share of coke fines was 20 (wt \%) in each of the test tube. After the test tube was taken out of the furnace it was frozen. The sedimentation of the solids was examined by visual examination.

\subsection{Effect of Using Internal By-Products in Blast Furnace}

The results from the viscosity measurements of mixtures were used to evaluate the effect of internal recycling of coking plant by-products on the total reducing agent use. When internal recycling is used to decrease the use of raw materials from outside of the system, some specifications have to be determined as to which reducing agent the decrease is assumed to influence. For example, if coal tar is injected into the blast furnace and it is assumed that it decreases the amount of coke required in the BF, the amount of coal tar also decreases because of the lowered coke production. If it is assumed that the use of coke production by-products in blast furnace decrease the use of oil, then the amount of coke remains nearly unchanged.

From the viscosity measurements, the maximum amount of solid particles in oil and coal tar mixtures could be derived. The total amount of coke fines that could be injected on a yearly basis, as oil and coal tar mixtures, depends on the viscosity limits and injection rates. An indicator that can be used to evaluate the recycling rate efficiency of the blast furnace-coking plant system was devised. Firstly the total reducing agent rate (RAR) in blast furnace can be presented as:

$$
\mathrm{RAR}=\mathrm{m}_{\text {coke }}+\mathrm{m}_{\text {injectanta }}
$$

where $m_{\text {coke }}$ is the coke rate in the blast furnace presented as kilograms per produced ton of hot metal $(\mathrm{kg} / \mathrm{tHM})$ and $\mathrm{m}_{\text {injectanta }}$ is the rate of injected reducing agents from the tuyéres $(\mathrm{kg} / \mathrm{tHM})$. Carbon in briquettes, which are used to recycle iron-bearing materials back to the blast furnace, are not considered as a reducing agent here, although it also has a minor effect on the coke rate. Secondly the indicator, describing the share of internally recycled reducing agents (IRRA-\%), was defined in Equation (2):

$$
\text { IRRA }-\%=\frac{m_{\text {coal tar }}+m_{\text {coke fines, oil }}+m_{\text {coke fines, coal tar }}}{\text { RAR }} \cdot 100 \%
$$


where $m_{\text {coaltar }}$ is the amount of injected coal tar $(\mathrm{kg} / \mathrm{tHM}), \mathrm{m}_{\text {coke fines, oil }}$ is the amount of coke fines in oil-coke fine mixture $(\mathrm{kg} / \mathrm{tHM})$, and $\mathrm{m}_{\text {coke fines, coaltar }}$ is the amount of coke fines in coal tar-coke fine mixture. The influence of recycled coking plant residues on reducing agent consumption was evaluated with simple coke replacement ratios (RR). The coke replacement ratio for auxiliary fuel is defined as the kilograms of coke that are displaced as a result of the injection of a kilogram of fuel. Tuyére-injected reducing agents have different coke replacement ratios, which depend mainly on the chemical properties of the injectant, carbon, hydrogen and ash content, and the amount of volatiles as well as the used injection rate. Geerdes et al. [13] give a RR of 1.17 for oil and 1.0 for coal tar. In the present calculation, RR for oil and coal tar was assumed to be 1.1. The pulverized coals used in the BF injection have RR below 1.0 [14]. The replacement ratio of coking plant residues was assumed to be 0.9 in the calculation.

The base year in the calculations was 2011, with proximate production values. The use of oil in Ruukki has varied much during past seven years, ranging from 130,000 $t$ in 2009 to over 290,000 $t$ in 2006 [15]. Hot metal production was approximately 2,000,000 $\mathrm{t}$ in 2011. The base case reducing agent rate was modified to correspond with consumption figures of Ruukki provided by Kinnunen et al. [16]. The average coke consumption for the various burden materials was 389 kilograms per produced ton of hot metal, and oil consumption was 81 kilograms per produced ton of hot metal. The total reducing agent consumption was $470 \mathrm{~kg} / \mathrm{t}$ hot metal. The annual consumption was 778,000 $\mathrm{t}$ of coke and $162,000 \mathrm{t}$ of oil. The coal tar injection amount was assumed to be 30,000 t per year, which is about $85 \%$ of the total annual coal tar amount.

\section{Results}

\subsection{Viscosity of Oil and Coke Fines Mixture}

Extra heavy bottom oil is bituminous at room temperature; in order to make it injectable into a blast furnace, the temperature has to be increased to near $200{ }^{\circ} \mathrm{C}$. Viscosity measures indicated that, at temperature of $200^{\circ} \mathrm{C}$ and shear rates of $30-851 / \mathrm{s}$, oil behaved like a Newtonian liquid. The viscosity of oil at $200{ }^{\circ} \mathrm{C}$ and $57 \mathrm{1} / \mathrm{s}$ shear rate was $25 \mathrm{cP}$, which is suitable for blast furnace injection.

The rheological behavior of oil and coke fine mixtures was almost Newtonian between shear rates of 30 to $85 \mathrm{1} / \mathrm{s}$. Viscosity remained almost constant and shearing stress increased linearly. Figure 3a shows the increase in viscosity when coke fines were added to the oil. In Figure $3 b$, the viscosity of the oil-coke fine mixture with standard deviations is presented for viscosity range of 0-100 cP. The viscosity measurements were done with a shear rate of $571 / \mathrm{s}$ and at four temperatures. At small addition rates, mixing of the mixture was feasible, but with larger solid particle share the mixture became rigid.

The viscosity of the mixture increases heavily after a certain share of solid particle amount addition and it is strongly influenced by temperature. By increasing the mixture temperature, the viscosity increase from solid particle addition can be compensated for. A coke fine share of $20 \mathrm{wt} \%$ in mixture at $200{ }^{\circ} \mathrm{C}$, which is the temperature of oil injection, increases the viscosity only $2.8 \mathrm{cP}$ on average. If the limit value of the accepted viscosity is $50 \mathrm{cP}$, the mixture could include $30 \mathrm{wt} \%$ coke fines. The highest percentual variation in the viscosity measurements of oil-coke fine mixture was with low viscosity values (below $40 \mathrm{cP}$ ) and smallest when viscosity was above $100 \mathrm{cP}$. 
Figure 3. (a) Viscosity of oil and coke fine mixtures and (b) the standard deviation of the viscosity measurements at different temperatures (with permissions of [17]).
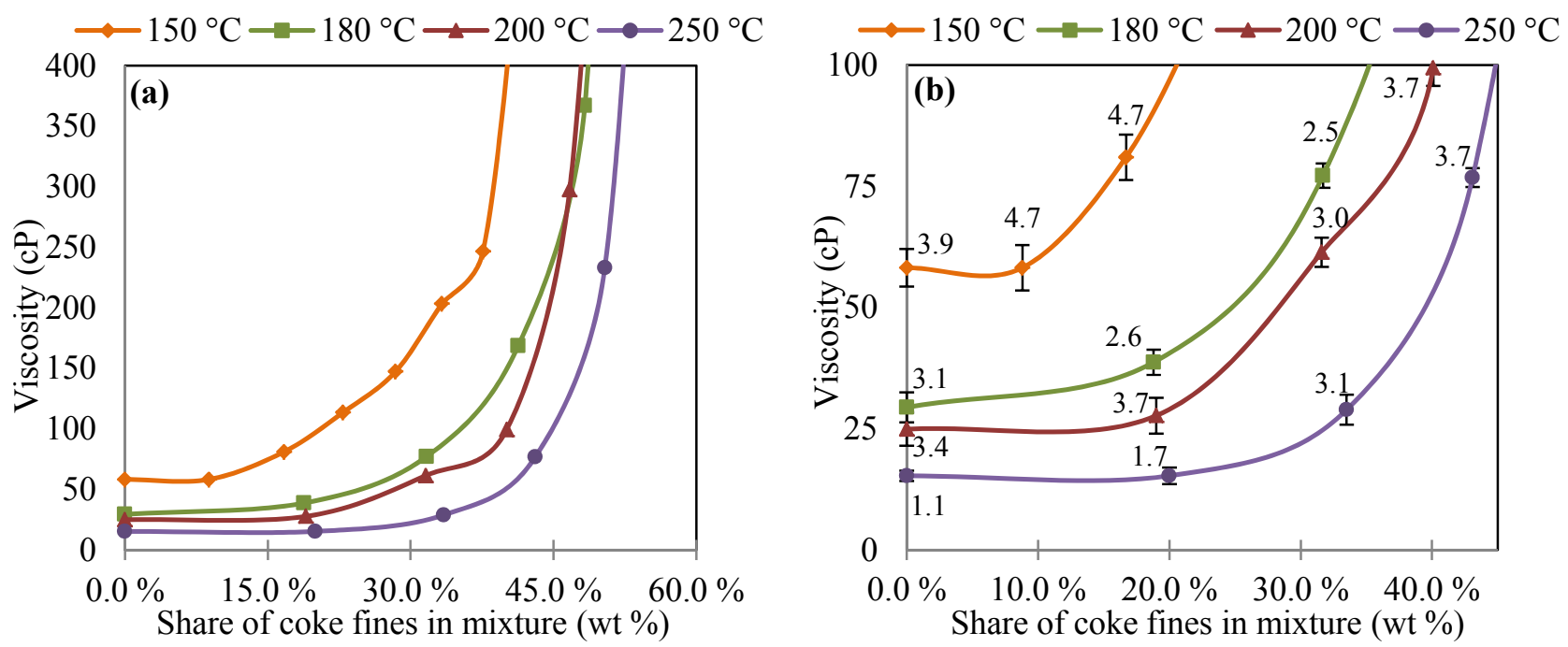

\subsection{Viscosity of Coal Tar and Coke Fines Mixture}

The viscosity of coal tar is strongly temperature dependent as was also the viscosity of the oil. Viscosity of coal tar was almost $1800 \mathrm{cP}$ at room temperature, but decreased rapidly when temperature was elevated. At $100{ }^{\circ} \mathrm{C}$, the viscosity was only around $10 \mathrm{cP}$. The rheological behavior of coal tar was Newtonian at temperatures of 55 and $75{ }^{\circ} \mathrm{C}$, between shear rates 20 to 100 1/s. With high shear rates (over 100 1/s) viscosity increases sharply, meaning dilatant behavior. The injection temperature of coal tar has to be kept around $80{ }^{\circ} \mathrm{C}$ because volatiles start to vaporize at higher temperatures. The viscosity of coal tar-coke fine mixture was measured with a constant shear rate of $571 / \mathrm{s}$. The temperatures of the viscosity measurements were set to 60,80 and $100{ }^{\circ} \mathrm{C}$ (Figure $4 \mathrm{a}$ ). In Figure $4 \mathrm{~b}$, the viscosity of the coal tar-coke fine mixture with standard deviations is presented for viscosity range of 0-100 cP.

The viscosity of the mixture increases rapidly when the mass share of coke fines exceeds $30 \%$. If the assumed injection temperature is $80^{\circ} \mathrm{C}$ and mass share of coke fines around $17 \%$, the viscosity of the mixture is $46 \mathrm{cP}$, which is still suitable for blast furnace injection and formation of droplets in the raceway region. The highest percentual variation in the viscosity measurements of coal tar-coke fine mixture was with low viscosity values (below $30 \mathrm{cP}$ ). When viscosity increased above $30 \mathrm{cP}$ the deviation decreased.

Sedimentation of the solids in oil-coke fine and coal tar-coke fine mixtures can be seen in Figure 5. The test tube on the left (Sample 1) in Figure 5a, is the oil sample after 8 days in the heating furnace. No sedimentation has been occurred even though there are small amount of solids also in the oil. From the oil-coke fine mixtures (Samples 2-4) it can be seen that solids have settled to the bottom of the test tube already after one day at the storage temperature $\left(170{ }^{\circ} \mathrm{C}\right)$ (Sample 2). The test tube on the right (Sample 8) in Figure 5b, is the coal tar sample after 7 days in the heating furnace at the storage temperature $\left(70{ }^{\circ} \mathrm{C}\right)$. No sedimentation can be seen. The settling of the coke fines in coal tar-coke fine mixtures (Samples 5-7) is slower than in oil-coke fine mixtures. After one day (Sample 5), no noticeable settling has been occurred in the test tube. After four (Sample 6) and seven days (Sample 7) coke fines have settled to the bottom of the test tube. 
Figure 4. (a) Viscosity of coal tar and coke fine mixtures and (b) the standard deviation of the viscosity measurements at different temperatures (with permission of [17]).
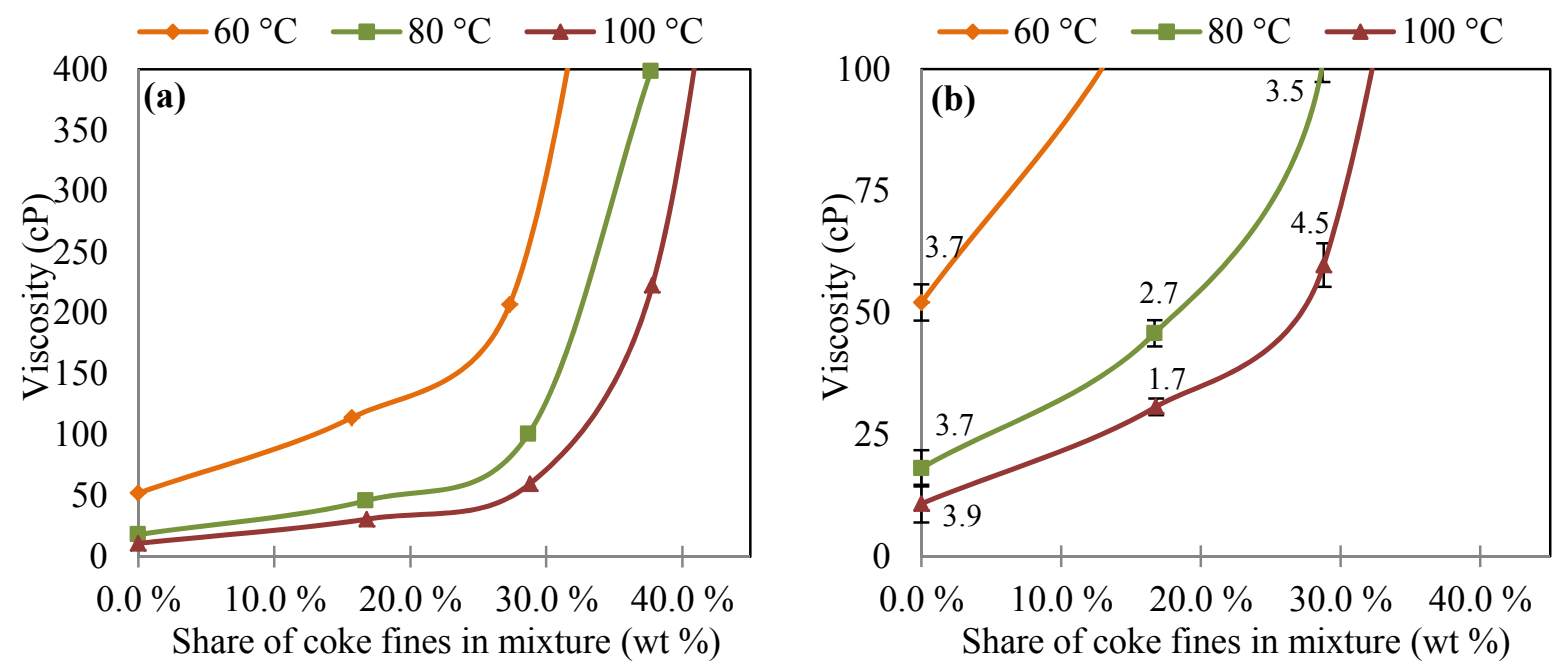

Figure 5. Sedimentation of (a) the solids in oil-coke fine mixture and (b) coal tar-coke fine mixture at the storage temperature (with permission of [17]).

(a)

Sample 1 Sample 2 Sample 3 Sample 4 8 days

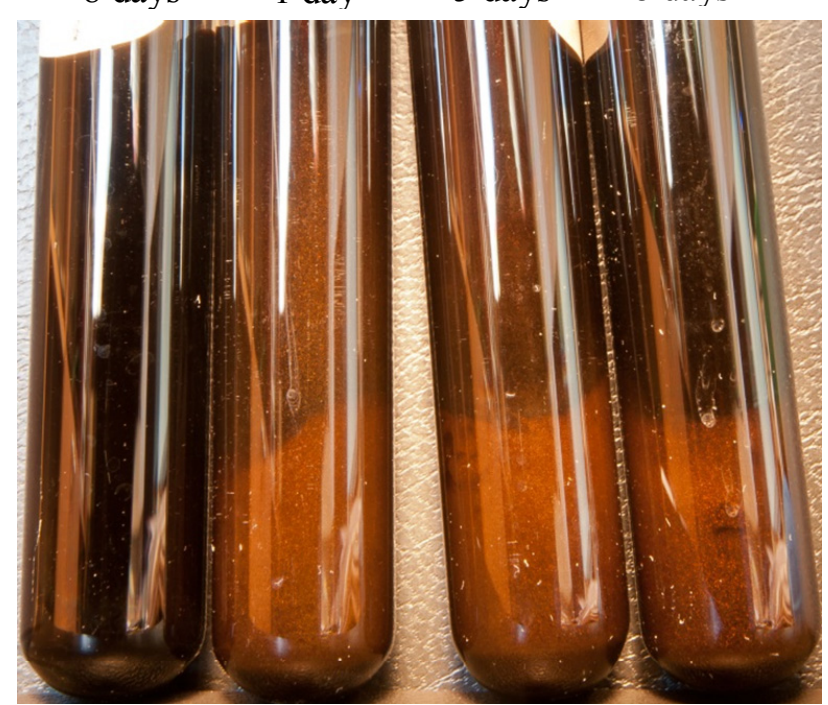

(b)

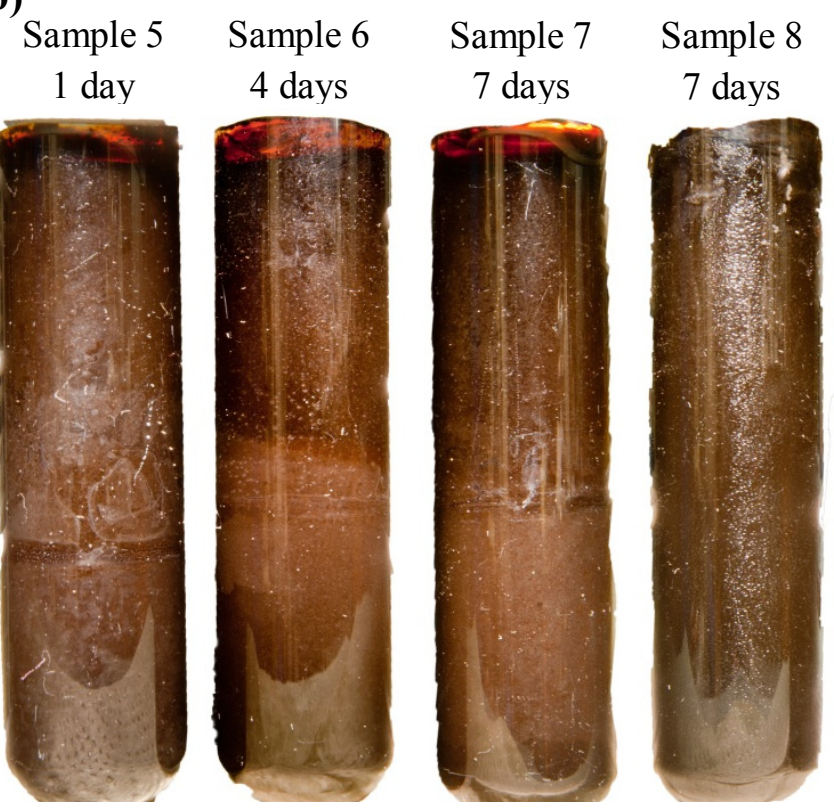

Simple sedimentation tests indicate that if liquid-solid injection practice would be applied there would be need for mixing of the slurry to ensure more uniform injectant flow to the BF. In test trials in 1980s the uniformity and desired temperature of coal-oil mixture (COM) was achieved with internal recirculation of $\mathrm{COM}$ from storage tank through grinding and transfer pumps and heat exchanger back to the storage tank [18].

\subsection{Injection Amounts of Coke Fines according to Viscosity Measurements}

By utilizing the results from viscosity measurements and attaining the annual amounts of used liquid injectants in Ruukki, the injection amount of solid carbonaceous residues can be calculated. The 
amount of solid residues (coke gravel, coke sand and coke dust) produced in 2011 was 56,000 t, of which only the coke dust is utilized, i.e., in the briquetting plant. To be able to inject all the rest of the solid residues $(40,000 \mathrm{t}$ ) as an oil-coke fine mixture, assuming that viscosity is maintained below $50 \mathrm{cP}$, the required amount of oil is approximately 101,000 t. This is a much lower oil amount than has been used on average. If it is assumed that the oil injection would be as in the base case $(162,000 \mathrm{t})$, total oil-coke fine mixture injection rate would be 202,000 $\mathrm{t}$ and the share of coke fines would be around $20 \mathrm{wt} \%$. With this mass share, the viscosity value of the mixture is well below $30 \mathrm{cP}$ at temperature of $200{ }^{\circ} \mathrm{C}$, which would be almost ideal for injection.

The amount of coal tar used in $\mathrm{BF}$ as a reducing agent is 30,000 $\mathrm{t}$ annually. From the viscosity measurement results, the critical mass share $(17 \mathrm{wt} \%)$ of coke fines in coal tar-coke fine mixture at $80{ }^{\circ} \mathrm{C}$ implies a total amount of $6000 \mathrm{t}$ of injection possibility. The viscosity measurements thus indicate that it would be possible to utilize all the coking plant solid residues as injectants.

\subsection{Blast Furnace Reducing Agent Consumption}

Another interesting point is to evaluate the impact of using internal residues on the blast furnace reducing agent rate. According to $\mathrm{BREF}$ for $\mathrm{BF}$, measures should be taken to decrease the amount of metallurgical coke in the blast furnace. However, the economic and environmental reasons may also apply for decreasing the use of other fossil-based reducing agents, such as the use of oil. The effect of coking plant residue injection on coke and oil consumption is examined next.

The effect of residue recycling on coke consumption was calculated by utilizing the plant data on the available residues for injection and by using the coke replacement ratios presented in Section 2.3. Table 2 presents the calculation results of anticipated reducing agent consumption with the assumption that the amount of oil was to remain unchanged when internal recyclables are injected. As can be seen, total reducing agent use remains nearly unchanged. Coke consumption could be decreased by nearly $9 \%$ if oil amount is kept constant and coal tar and coke fines are used.

Table 2. Use of reducing agents when oil amount is kept constant and coke amount is altered.

\begin{tabular}{cccccccc}
\hline $\begin{array}{c}\text { Reducing agent } \\
\text { use scenario }\end{array}$ & $\begin{array}{c}\text { Coal tar } \\
(\mathbf{k g} / \mathbf{t H M})\end{array}$ & $\begin{array}{c}\text { Coke fines } \\
(\mathbf{k g} / \mathbf{t H M})\end{array}$ & $\begin{array}{c}\text { Oil } \\
(\mathbf{k g} / \mathbf{t H M})\end{array}$ & $\begin{array}{c}\text { Coke } \\
(\mathbf{k g} / \mathbf{t H M})\end{array}$ & $\begin{array}{c}\text { Total } \\
(\mathbf{k g} / \mathbf{t H M})\end{array}$ & $\begin{array}{c}\text { Coke } \\
\mathbf{( t / a )}\end{array}$ & IRRA-\% \\
\hline Base scenario & 0.00 & 0.00 & 81 & 389 & 470 & 778,000 & 0.00 \\
$\begin{array}{c}\text { Coal tar added } \\
\text { Coal tar and }\end{array}$ & 15 & 0.00 & 81 & 373 & 469 & 745,000 & 3.2 \\
coke fines added & 15 & 20 & 81 & 355 & 471 & 709,000 & 7.4 \\
\hline
\end{tabular}

The share of internally recycled reducing agents in the total reducing agent use is $3.2 \%$ when coal tar injection is applied. However, if coke fines are utilized as well, IRRA-\% could increase to the level of $7.4 \%$. This is a significant proportion of total reducing agent use. It should also be remembered that reduction in coke consumption decreases the production rate in the coking plant, which also decreases the amount of residues. Alternatively, the high priced coke could be sold.

Another option could be to decrease the amount of injected oil by utilization of coal tar and coke fines. These options are illustrated in the calculated figures in Table 3. By using the same replacement ratios as in the coke consumption calculation, the total decrease in oil consumption on a yearly basis 
could be $62,300 \mathrm{t}$, almost $39 \%$. An oil amount of $99,300 \mathrm{t}$, however, is less than the amount required to fully mix the solid residues with oil $(101,000 \mathrm{t}$ with viscosity below $50 \mathrm{cP})$. By increasing the injection temperature and thereby lowering the viscosity, this case is also possible.

Table 3. Use of reducing agents when coke amount is kept constant and oil amount is altered.

\begin{tabular}{cccccccc}
\hline $\begin{array}{c}\text { Reducing agent } \\
\text { use scenario }\end{array}$ & $\begin{array}{c}\text { Coal tar } \\
(\mathbf{k g} / \mathbf{t H M})\end{array}$ & $\begin{array}{c}\text { Coke fines } \\
(\mathbf{k g} / \mathbf{t H M})\end{array}$ & $\begin{array}{c}\text { Oil } \\
(\mathbf{k g} / \mathbf{t H M})\end{array}$ & $\begin{array}{c}\text { Coke } \\
(\mathbf{k g} / \mathbf{t H M})\end{array}$ & $\begin{array}{c}\text { Total } \\
(\mathbf{k g} / \mathbf{t H M})\end{array}$ & $\begin{array}{c}\text { Oil } \\
(\mathbf{t} / \mathbf{a})\end{array}$ & IRRA-\% \\
\hline $\begin{array}{c}\text { Base scenario } \\
\text { Coal tar added }\end{array}$ & 0.00 & - & 81 & 389 & 470 & 162,000 & 0.00 \\
$\begin{array}{c}\text { Coal tar and } \\
\text { coke fines added }\end{array}$ & 15 & - & 66 & 389 & 470 & 132,000 & 3.2 \\
\hline
\end{tabular}

From the technological and economic perspective, it would be more beneficial to blend solid coking plant by-products with oil only. A liquid-solid mixture needs to be mixed to assure as homogenous blend as possible. Modifications would also have to be made to the piping and injection system to allow mixture injection. Studies conducted on coal and oil mixtures in the 1980s [7] have proved that injection of such mixtures is technologically feasible, which encourages further evaluation of the novel coking plant by-product utilization.

This study ignored the combustion behavior of injectants in the tuyére and raceway regions and the impacts on the adiabatic flame temperature (AFT). These are important factors that should be evaluated before injecting liquid-solid mixture to the BF. Combustion of injectants is also related to the required amount of oxygen enrichment of the blast, which might change if considerable changes occur in injection practice. However, it is anticipated that no major changes in oxygen enrichment would be needed if changing from oil injection to slurry injection. The share of combustible elements $(\mathrm{C}, \mathrm{H}, \mathrm{S})$ would not increase compared to oil injection, if injection amount is kept constant. On the contrary, the amount of combustibles would decrease. Coking plant solid residues are almost free of volatile matter, which lower the AFT, but then they include ash that has to be melted. No need for additional oxygen enrichment and only minor change in flame temperature was reported by Mertdogan et al. [18] when changing from oil injection to COM injection.

Figure 6 presents the applicable region of coke and oil consumption per produced ton of hot metal (HM) with different reducing agent use scenarios. The point in upper-right corner presents the base case scenario where coke consumption is $389 \mathrm{~kg} / \mathrm{tHM}$ and oil consumption is $81 \mathrm{~kg} / \mathrm{tHM}$, total reducing agent consumption being $470 \mathrm{~kg} / \mathrm{tHM}$. The following changes are marked in Figure 6: (a) Coal tar injection replaces part of the oil input; (b) Coal tar and coke fine injection replaces part of the oil input; (c) Coal tar injection replaces part of the coke input; and (d) Coal tar and coke fine injection replaces part of the coke input. In theory, any point inside the grey region could be a possible recycling option.

The selection of the reducing agent mix depends highly on the cost. Also, the production rate and controllability of the furnace are factors that have influence on reducing agent selection. Coking plant residues provide an alternative source of reducing agents, which currently necessitate considerable cost. Thus their utilization as reducing agents could be an economically justified alternative. 
Figure 6. Applicable region of reducing agents.

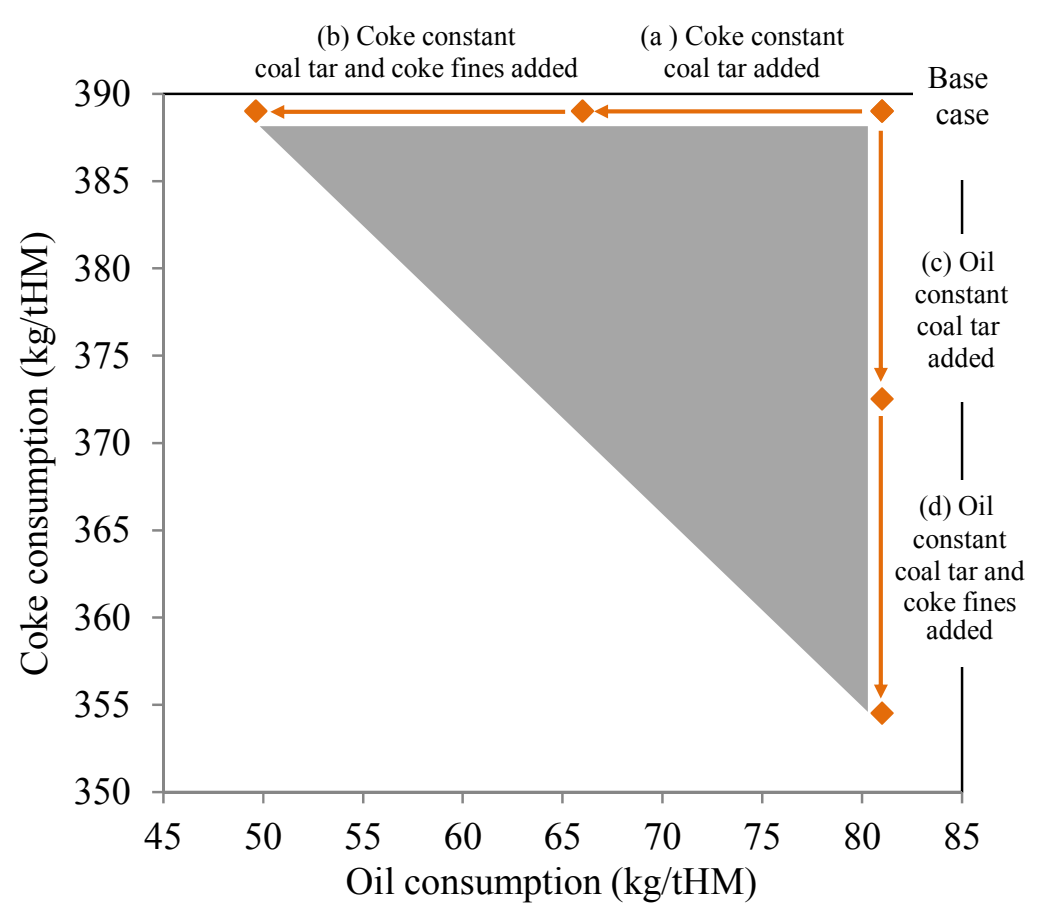

\subsection{Direct and Indirect Impacts of Recycling Solid Coking Plant By-Products inside Steel Plant System}

This section is dedicated to evaluation of direct and indirect environmental impacts of recycling solid coking plant by-products inside steel plant boundaries. Special emphasis is placed on the case where coke consumption is decreased by utilization of coking plant by-products, because it has been defined as BAT measure in ironmaking [6]. Reducing agent consumption was estimated to remain in the region of 469-474 kg/tHM in all the evaluated scenarios. Carbon dioxide emissions from energy inputs to blast furnace are between 1508 and $1525 \mathrm{~kg} / \mathrm{tHM}$ [19]. Annually, $\mathrm{CO}_{2}$ emissions are 3.015-3.049 Mt, if $2.0 \mathrm{Mt}$ hot metal production is assumed. The highest total $\mathrm{CO}_{2}$ emissions are anticipated to result from the use of coal tar and coke fines beside with constant coke rate and decreased oil rate. This is simply because oil is more efficient reducing agent than coke fines [13]. Interesting notion can be made on the source of the reducing agents used in different scenarios. In base scenario reducing agents are entirely sourced outside the system boundary 1 (Figure 2). In other scenarios where coking plant residues are utilized inside the system boundary 1, raw material rate from the system boundary 2 decreases. $\mathrm{CO}_{2}$ emissions arising from "virgin" reducing agents (outside system boundary 1) could be as low as $1401 \mathrm{~kg} / \mathrm{tHM}$.

Utilizing of coking plant by-products inside steel plant may also contribute to increased energy consumption due to extra processing steps. In case of a coal tar injection there are no extra processing steps besides the pumping of the coal tar from storage silos to blast furnace tuyéres. Solid coking plant by-products must be grinded to fine particles before mixing with oil or coal tar. According to Esteban and Carrasco [20], the electricity requirement of coal pulverization is between 7 and $36 \mathrm{kWh} / \mathrm{t}$. Coking plant by-products are anticipated to require more intensive milling because they have undergone plastic deformation during the coking process. If it is assumed that solid coking plant by-products require $40 \mathrm{kWh}$ electricity per ton, the annual electricity consumption for pulverizing coke sand and 
coke gravel (40,000 t) would be $1600 \mathrm{MWh}$. In 2011, the total electricity consumption in Ruukki steel plant was 77,600 MWh [15]. Indirect $\mathrm{CO}_{2}$ emissions, if it is assumed that electricity would be bought from the market, would be $336 \mathrm{t}$ [21].

Resource efficiency of the steel plant would be significantly improved due to utilization of coking plant residues inside steel plant. Some $1.5 \mathrm{t}$ of coking coal is needed to produce one ton of coke for blast furnace, calculated from the figures presented in Section 2.1. The minimum amount of coke in defined recycling scenarios was calculated as $355 \mathrm{~kg} / \mathrm{tHM}$. This implies over 104,000 $\mathrm{t}$ reduction in coking coal need. Coal mining and transportation require the use of fossil fuels and result in fossil $\mathrm{CO}_{2}$ emissions [22,23]. Wikström et al. [24] have estimated that indirect emissions resulting from coking coal supply (coal mining and transportation) to Sweden is $51.4 \mathrm{~kg} / \mathrm{t}$ coal. This figure can be used to evaluate the decrease in indirect $\mathrm{CO}_{2}$ emissions also in Finnish steel plant context. Indirect $\mathrm{CO}_{2}$ emission savings from decreased use of coking coal would be $5360 \mathrm{t}$. Additional energy input is further needed and $\mathrm{CO}_{2}$ emissions caused, if solid coking plant by-products (coke sand and coke gravel) are transported to be used in other applications either in Finland or abroad. In addition to indirect $\mathrm{CO}_{2}$ emission reduction, decrease in coke production rate results in decrease in direct $\mathrm{CO}_{2}$ emissions from the coking process. Due to slightly lowered production rate, process gases from blast furnace and coke ovens can be used in other applications inside the steel plant.

Same kind of assessment could be done also to cases, in which coke rate is kept constant and the amount of oil is decreased. Since extra heavy bottom oil is the by-product of crude oil distillation, it is challenging to allocate suitable amount of environmental impacts to it. In this assessment the analysis of wider impacts on the replacement of extra heavy bottom oil with solid coking plant by-products is ignored. More thorough analysis of life cycle impacts of steel production stages in Finnish context has been performed by Seppälä et al. [25].

\section{Conclusions}

In this paper the possibility to increase resource efficiency in a Finnish steel plant was investigated. The research concentrated mainly on a coking plant-blast furnace system by analyzing the feasibility of recycling coking plant residues into a blast furnace as reducing agent. Additionally, the impact on direct and indirect greenhouse gas rates was shortly assessed. The steelworks in question uses coke and liquid extra-heavy bottom oil and coal tar as reducing agents in its normal operations. The applied injection technology sets limits for the utilization of solid coking plant residues. Viscosity measurements conducted with oil-coke fine and coal tar-coke fine mixtures showed that it would be possible to utilize all the residues from the coking plant as BF reducing agents. However, emphasis has to be paid to adequate mixing of mixtures through pumping or stirring.

According to the analysis in the paper, coke consumption could be decreased by nearly $9 \%$ when coal tar and coke fines are recycled to the blast furnace and oil injection is kept at a constant level. In reality, this figure would be slightly lower because a reduction in coke requirement would also decrease the amount of coking plant residues. If the oil is replaced and the coke rate kept constant, the decrease in the oil consumption could be almost 39\%. Recycled internal carbonaceous residues could constitute up to approximately $7.4 \%$ of total reducing agent consumption, which can be considered a substantial share. Utilization of internal residues could provide a sustainable option for increasing 
resource efficiency in integrated steelworks, and also save money. The investments required to facilitate liquid-solid injection would be moderate. Equipment would be needed to grind the coking plant by-products into pulverized form, and some modification of oil and coal tar tanks would also be needed to facilitate adequate mixing of liquid and solid fractions.

Analysis of the major sources of $\mathrm{CO}_{2}$ emissions, resulting from increased internal utilization of solid coking plant by-products reveal that there would be more positive than negative impacts. Direct $\mathrm{CO}_{2}$ emissions from coke making could be decreased through the lower coke production rate. Indirect $\mathrm{CO}_{2}$ emissions would arise from increased use of electricity due to pulverization of solid coking plant by-products. $\mathrm{CO}_{2}$ emissions from electricity use are modest, also because of the fact that the average emission factor for electricity is low in Finland. Lower coke production rate would result in savings in indirect $\mathrm{CO}_{2}$ emissions (coal mining and transportation) and would be more significant than those arising from increased electricity consumption of solid by-product pulverization.

\section{Acknowledgments}

The laboratory experiments have been conducted by Antti Salo within his M.Sc. work. His thorough work is gratefully acknowledged. We thank the personnel of Ruukki, who gave valuable information and comments concerning the manuscript. The Graduate School in Chemical Engineering (GSCE) is gratefully acknowledged for its financial support.

\section{References and Notes}

1. World Steel Association. Steel Statistical Yearbook 2012; World Steel Association: Brussels, Belgium, 2012. Available online: http:/www.worldsteel.org/dms/internetDocumentList/bookshop/ Steel-Statistical-Yearbook-2012/document/Steel\%20Statistical\%20Yearbook\%202012.pdf (accessed on 5 January 2013).

2. Das, B.; Prakash, S.; Reddy, P.S.R.; Misra, V.N. An overview of utilization of slag and sludge from steel industries. Resour. Conserv. Recycl. 2007, 50, 40-57.

3. Shatokha, V.I.; Gogenko, O.O.; Kripak, S.M. Utilising of the oiled rolling mills scale in iron ore sintering process. Resour. Conserv. Recycl. 2011, 55, 435-440.

4. Singh, M.; Björkman, B. Effect of processing parameters on the swelling behaviour of cement-bonded briquettes. ISIJ Int. 2004, 44, 59-68.

5. Doronin, I.E.; Svyazhin, A.G. Commercial methods of recycling dust from steelmaking. Metallurgist 2011, 54, 673-681.

6. Remus, R.; Aguado Monsonet, M.A.; Roudier, S.; Sancho, L.D. Best Available Techniques (BAT) Reference Document for Iron and Steel Production: Industrial Emissions Directive 2010/75/EU (Integrated Pollution Prevention and Control); Publications Office of the European Union: Luxembourg, 2013.

7. Yabe, S.; Iba, T.; Miyazaki, T.; Satoh, K.; Kojima, M.; Aminaga, Y. COM and CTM injection into all tuyeres of Kashima No.3 blast furnace. Ironmak. Proc. Metall. Soc. AIME 1983, 42, 541-547.

8. Makkonen, H.T.; Heino, J.; Laitila, L.; Hiltunen, A.; Pöyliö, E.; Härkki, J. Optimisation of steel plant recycling in Finland: Dusts, scales and sludge. Resour. Conserv. Recycl. 2002, 35, 77-84. 
9. Diemer, P.; Killich, H.J.; Knop, K.; Lüngen, H.B.; Reinke, M.; Schmöle, P. Potentials for utilization of coke oven gas in integrated iron and steel works. In Second International Meeting on Ironmaking; First International Symposium on Iron Ore: Espírito Santo, Brazil, 2004.

10. Babich, A.; Senk, D.; Fernandez, M. Charcoal behavior by its injection into the modern blast furnace. ISIJ Int. 2010, 50, 81-88.

11. Andahazy, D.; Slaby, S.; Löffler, G.; Winter, F.; Feilmayr, C.; Bürgler, T. Governing processes of gas and oil injection into the blast furnace. ISIJ Int. 2006, 46, 496-502.

12. Parikh, J.; Channiwala, S.A.; Ghosal, G.K. A correlation for calculating HHV from proximate analysis of solid fuels. Fuel. 2005, 84, 487-494.

13. Geerdes, M.; Toxopeus, H.; van der Vliet, C. Modern Blast Furnace Ironmaking-An Introduction, 2nd ed.; IOS Press: Amsterdam, The Netherlands, 2009; pp. 47-57.

14. Ariyama, T.; Murai, R.; Ishii, J.; Sato, M. Reduction of $\mathrm{CO}_{2}$ emissions from integrated steel works and its subjects for a future study. ISIJ Int. 2005, 45, 1371-1378.

15. Ruukki Web Page. Environmental Data Monitor. Available online: http://www.ruukki.com/ Corporate-responsibility/Environment/Environmental-data-monitor (accessed on 5 January 2013).

16. Kinnunen, K.; Paananen, T.; Lilja, J. Modelling and simulation of Blast Furnace Process for switch from Sinter to Pellet Operation. In Proceedings of 4th International Conference on Modelling and Simulation of Metallurgical Processes in Steelmaking, Düsseldorf, Germany, 27 June-1 July 2011.

17. Salo, A. The Viscosity Measurements of Blast Furnace Injectants [in Finnish]. Master's Thesis, University of Oulu, Oulu, Finland, 5 April 2012

18. Mertdogan, A.; Marlin, L.A.; Beaucair, V.D.; Jansto, S.G. Production and use of coal-oil mixture as blast furnace auxiliary fuel. Ironmak. Proc. Metall. Soc. AIME 1983, 42, 593-606.

19. It is assumed that all the carbon entering to blast furnace is transformed into $\mathrm{CO}_{2}$. In practice hot metal has C-content of $4.5 \%$, which is decreased close to zero in basic oxygen furnace. Carbon content of coke, oil, coal tar and coke fines are assumed to be $88 \%, 87 \%, 88 \%$ and $87 \%$ respectively.

20. Esteban, L.S.; Carrasco, J.E. Evaluation of different strategies for pulverization of forest biomasses. Powder Technol. 2006, 166, 139-151.

21. The average Finnish emission factor for electricity is $210 \mathrm{~kg} / \mathrm{MWh}$.

22. Ditsele, O.; Awuah-Offei, K. Effect of mine characteristics on life cycle impacts of US surface coal mining. Int. J. Life Cycle Assess. 2012, 17, 287-294.

23. Mangena, S.J.; Brent, A.C. Application of a Life Cycle Impact Assessment framework to evaluate and compare environmental performances with economic values of supplied coal products. J. Clean. Prod. 2006, 14, 1071-1084.

24. Wikström, J.O.; Grip, G.E.; Larsson, M.; Ångström, S. Ways to Reduce $\mathrm{CO}_{2}$ Emissions at SSAB Luleå Works. In Proceedings of 2 nd International Conference on New Developments in Metallurgical Process Technology, Riva del Garda, Italy, 19-21 September 2004.

25. Seppälä, J.; Koskela, S.; Melanen, M.; Palperi, M. The Finnish metals industry and the environment. Resour. Conserv. Recycl. 2002, 35, 61-76.

(C) 2013 by the authors; licensee MDPI, Basel, Switzerland. This article is an open access article distributed under the terms and conditions of the Creative Commons Attribution license (http://creativecommons.org/licenses/by/3.0/). 